\title{
The Roles of Community for the Growth of Micro and Small Enterprises in Banjarmasin, Indonesia
}

\author{
Ni Nyoman Suarniki ${ }^{\# 1}$, Sirajuddin Omsa ${ }^{* 2}$ \\ ${ }^{\text {\#Management Department, STIE Nasional }}$ \\ Banjarmasin, Indonesia

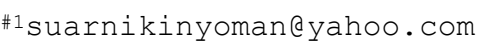 \\ *Accounting Department, State Polytechnic of Ujung Pandang \\ Makassar, Indonesia \\ ${ }^{*}{ }^{2}$ sirajud_omeyahoo.com
}

\begin{abstract}
This study examines the role of the community for the development of micro and small enterprises in Banjarmasin, Indonesia. The research aims to explore the benefits of information exchange among community members and explore the community utilization for the development of their business. The research also aims to review the role of community for the members. This research is a qualitative research using phenomenology approach. Research objects are community members of micro and small enterprises, while Informants in this study amounted to 5 (five) people consisting of two micro entrepreneurs and 3 three small entrepreneurs. The research analysis tool used is Phenomenology. The results of this study indicate that the interaction of micro and small business community members through WhatsApp (WA) group is very dynamic. The networking that occurs among community members is not only a common friendship but also sharing of business information, business transactions, and business partnerships. Community members feel very helpful in doing business with the community existence. Many members increase their sales turnover because they are actively involved in WA group. This is because trough WA group, the community members can promote their products and/or services freely. Furthermore, information sharing is regularly done through WA groups, such as business plan preparation training, exhibition activities, access to cheap and quality raw materials, potential business opportunities, financial governance, and business legality management. Hence, community can bridge connectivity among members, resulting in a growing sense of togetherness and loyalty among them.
\end{abstract}

Keywords - Community Member, Micro and Small Enterprises, Whatsapp, Information Sharing

\section{INTRODUCTION}

Information technology plays a very important role in helping people to facilitate in carrying out their daily activities, whether in operating the business, dealing with clients, or communicating with family, friends and others. Communication is a very important in life, one cannot live alone, they need others to support their life, therefore they tend to live in groups. The group will work well and benefit its members, if among them there is a matching view and harmony of relationships.

Today, many groups are formed, not only in the form of political organizations, but also in the form of community organizations, religious organizations and other formal organizations. In addition, informal groups based on friendships are also growing with the use of social media such as Facebook (Fb), Twitter, Instagram, Telegram, Line, WhatsApp, and others. In line with the development of social media and a significant change in the lifestyle of the community, a group that is often called community becomes a necessity. This happens allegedly because the community has great benefits for its members. What benefits does a member of his or her community have? The answer to this question will be investigated in this study.

\section{PROBLEMS AND RESEARCH FOCUS}

\section{A. Research Problems}

In the global economic fluctuations, it has been proven that micro and small enterprises are more resilient than middle and large businesses. In Indonesia, there are quite a lot of micro and small businesses that stand with various background motives. Some are standing because of the demands of life or not getting another job or the limited field of employment for the skills they have, but no less standing for wanting to develop themselves. Regardless of what the motive is, in its development, many micro and small enterprises (MSEs) are not growing, some are growing and rising levels for examples from micro-enterprises to small, or from small to medium- sized businesses, even from medium-sized businesses into large one. 
There is also the opposite, and some even close or bankrupt, because it is unable to compete.

Many factors influence the growth of a business process. Micro and small enterprises are synonymous with weaknesses, such as low quality of human resources, poor financial management, production techniques that rely on human labor, marketing strategies that have not yet subsided customer satisfaction, and leadership that is still very weak. Therefore, micro and small enterprises need help from various parties. Through related institutions, the government has been appointed to contribute to the growth or development of MSEs in Indonesia. Some examples of assistance that have been provided by the Ministry of Industry and Trade, and the Office of Cooperatives and SMEs are training, mentoring, access to capital, and so forth. Furthermore, the main task of MSEs is to utilize such assistance efficiently and effectively.

In addition to share government-assisted capital assistance and assistance from CSR, community building among MSEs is also expected to assist members in developing their members' businesses, such as sharing of the cheapest raw material information, market potential, production techniques, marketing strategies, business licensing, and other important business information. Based on the above phenomenon, the problems in this research are:

- What does networking mean for community members?

- How do members use their community for MSE business development?

\section{B. Research Focus}

This study focuses on investigating the role of the business community for the advancement of its members' businesses. In-depth reviews are also conducted to uncover members' perceptions of the community's existence and the contribution of members that can be shared with other community members. This study will also examine the aspects of harmony between the members and the community to create a harmonious relationship so that members' businesses can be increased as well as advanced to a higher level.

\section{LITERATURE REVIEW}

\section{A. Business Theory}

There are 3 aspects to keep in mind that the business theory used is always relevant for the present and future, such as reality, focus, and change [2]. Companies must well recognize the environmental conditions encountered, whether internal conditions that include the advantages and disadvantages, such as resources owned, and external conditions that include opportunities and threats, such as consumer tastes, market potential, technological changes, and other external conditions. By understanding the internal and external environmental conditions, the company is expected to focus on the target to be achieved in accordance with the reality of the company's capabilities and current market conditions. Furthermore, change is something that will happen continuously, hence companies should be able to adapt in order to support business focus and continuous improvement, so that the company is able to meet customer expectations as the key to business success.

\section{B. Relationship Management}

Business competition increasingly sharp and will be more severe in the future. If the company cannot implement the right strategy to win the hearts of consumers, and cover the weaknesses by building a business partnership, then most likely the undertakings cannot survive as expected. The benefits of this partnership are unquestioned, hence [3] believes in criticizing SMEs who lack networking attention by stating that most SMEs view networking as a non-priority factor. According to him, SMEs often prefer to increase sales turnover or seek capital rather than networking, whereas networking can help to increase sales turnover and ease in obtaining additional capital, and other networking benefits for SMEs.

By knowing the 7 benefits of networking for small and medium enterprises below, it is expected SMEs can start doing networking on a regular basis. The seven benefits are: (1) increasing sales, (2) opening new opportunities, (3) obtaining important suggestions and feedback, (4) getting positive influence, (5) increasing credibility, (6) increasing confidence, and (7) broaden the horizons. 
According to [4], creativity becomes very important because it refers to new products of value and the capacity to produce a work. By seeing, hearing, observing, imitating and modifying, highly competitive products will be generated. In other words, competitiveness will arise from creativity that focuses on the consumers wants and needs. It is important for organizations to enhance the capacity of leaders and employees to create sustainable growth through broad and sustainable networking.

Furthermore, trust becomes fundamental in establishing good relationships with colleagues and consumers. Since trust is very profitable, it must be realized and maintained. According to [5], trust is a reflection of two component. Firstly, credibility based on the size of an organization's trust in another organization, where it requires expertise to produce work effectiveness and reliability. Secondly, benevolence which can be interpreted as good deeds, generosity, charity and deeds of its kind to colleagues, consumers and society. [6] divide trust into four categories: competence, virtue, integrity and predictability. The trust that every company needs can be created if the company's staff has competencies in managing the business. Competencies that are added with virtues such as hospitality, service and sufficient explanation to the consumer, with high integrity can create relationships in the long run. Long-term relationships that have been built, is expected to generate high consumer loyalty. Loyalty is an important part of marketing, especially in developing a marketing strategy plan to improve company's competitiveness, which is expected to increase its profit and growth [7].

\section{Phenomenology}

This research uses phenomenology approach in its research. According to [1] Phenomenology research are an approach in which a thinking that reflects individual thoughts based on personal experiment which involves the subject in doing so. Empirical phenomenology is a subjective perspective on that individual personal experience which gained from the individual live experience derived from a phenomenon [8]. The main idea on empirical phenomenology is a scientific explanation based on the meanings and words interpreted from the subject involved [9].

Empirical resulted in an explanation based on subjective experience that is experienced by individual, derived from an actual individual experience. When using the empirical phenomenology, researcher needs to take into account a description based on existing idea that reflects on how that individual thinks on certain phenomena, in this process the researcher usually required to interact and learn from the individual. It is meant to give a rational option for the individual involved in the research. Rational option is a controlled subjective on the individual that is involved in the research. The usage of empirical phenomenology can explain the phenomena from the subject involved in how they make a business relationship. Information that is given can illustrates an actual event from the individual during their interaction in their own business community [1].

\section{IV.RESEARCH METHODS}

This research is designed qualitatively, that is trying to construct reality and understand its meaning. The main factor to be considered in qualitative research is the process [10]. In viewing research issues in terms of multidisciplinary sciences, domains, and research subjects are part of a tradition of positive thinking and cultural-related perspectives and interpretive studies [11].

The object of this research is the members and managers of the business community. In this study, objects are linked to how interactions among members, between members and managers, and how the community contributes to the growth and development of members' businesses.

Data were collected with 3 (three) methods: indepth interview, observation and article searching through website. The place of the interview is determined according to the agreement between the informants and the researcher, at the café, at the informants' house or other agreed place.

The selection technique of the key informant used snowball. This technique connects people to each other either directly or indirectly (Kenneth and David Ermman, 1977, in [1]. 
TABLE I

RESEARCH INFORMATION

\begin{tabular}{|c|l|l|}
\hline No. & \multicolumn{1}{|c|}{ Name } & \multicolumn{1}{|c|}{ Positio } \\
\hline 1. & Asmah Darkani & $\begin{array}{l}\text { Chairman of DPD Hipmikimdo } \\
\text { South }\end{array}$ \\
\hline 2. & Hj. Bahrudin & $\begin{array}{l}\text { Chairman of Anugrah community, } \\
\text { admin groun. }\end{array}$ \\
\hline 3. & Siti Asnah & Community members \\
\hline 4. & M. Nurullah & Member \\
\hline 5. & Mariatul Asiah & $\begin{array}{l}\text { LK3 Management, head of } \\
\text { women empowerment program. }\end{array}$ \\
\hline
\end{tabular}

Data validation was done by involving informants, such as transcripts of interviews that have been compiled submitted back to the informant to be revised without changing the intent of the results of previous interviews. The result was not found inconsistency, so it can be stated that the data used in this research was valid. Furthermore, data was analyzed using phenomenology method [12]. Kleiman (2004) [12] presents several phenomenological methods, namely:

- Read carefully the transcript of the interview in order to obtain a comprehensive picture of the interview results contained in the transcript of the interview.

- Read interview transcripts more thoroughly and divide the data into sections corresponding to the same quotations.

- Integrate quotations with the same parts.

- Integrating the pieces or interview quotes into the subject of meaning.

- Describe the meaning of the interview quote.

- Describe the findings and the meaning of research.

- Reviewing the findings of the study by comparing it with previous interview transcripts.

- Verify, criticize, and synchronize the research findings to suit the research objectives.

The presence of researchers in qualitative research is absolutely necessary because they are the direct instrument of the data collection research [13]. Researchers went and met the informants directly and conduct interviews with informants. The observations were made at several community meetings and community activities on social media, especially WhatsApp and Line. Researchers were also members of the business community and some social media communities. The researcher's experience can provide broad insights that can be used to guide the direction of the research to fit the established research objectives.

The informants in this study are 5 people, consist of 2 community managers and 3 members of business community. The basis for determining the number of informants for 5 people is that informants no longer provide information that varies. Selection of new informants no longer need to be done if no new information is found or has reached the level of saturation (redundancy). At this stage, the information gathering process is considered complete. Here are the names of the informants and the information.

\section{RESEARCH RESULTS}

\section{A. Community and Business Activities}

In line with the advancement of information technology, cyberspace community emerging a lot of good pure friendship, business, politics and other purposes. This means is often a forum for discussion, exchange of information, learning, business, and other phenomena.

This study focuses on how community members use of their community for ongoing business progress and for non-

business members what positive values can be gained from the communities they participate in or where they belong.

The results of in-depth interviews with informants, the community has a huge contribution for members, especially for young entrepreneurs and new start up efforts. Benefits derived such as a member initially introduces the product, then another member responds, there are members who recommend the use or repair of the packaging, other members want to try the product, and other responses. At this stage there will be a long interaction as initially difficulty when purchasing large quantities of packaging, but with some members who need the same products, the purchase of packaging can be done in groups, so that the packaging improvement program can be done. Other information, such as information on free or paid training, can also be shared in this community.

In this community, the members can also seek information about the source of cheap raw materials, merchandise that has potential profit, competent 
workforce, location / place of business sold or rented, and other business information. This forum is also often used as a joke to refresh the atmosphere. When meeting directly will be more exciting again, because previously members of the community have not known each other, but through this community, friendship will spread very fast, so even though joined in a community, but never before met directly. Thus, the chat will get crowded, and most likely business transactions will also occur, such as a small exhibit without sponsorship. That is like a bazaar held by the community on the anniversary, big holidays like the month of fasting, new year, and so forth, in one place agreed for example the home page belongs to members or borrow a place in the yard of the mosque or church.

Increased insight and supported by ATM stance (Observe, Imitate, and Modify) make the passion to advance more encouraged. There are many members who recognize that this community is helping the progress of their business, even some members who initially did not have a business, after joining the community member has become a start-up business. Through the community, members can also refine each other how to manage the business, so that more orderly their business administration. No less important is related to the licensing process. In this regard, chairman of DPD Hipmikimdo (association of micro, small and medium enterprises, Indonesian) branch of South Kalimantan has provided assistance to entrepreneurs who want to create a business license and access to banking.

\section{B. Benchmarking}

Business strategies run by members of the community in general only from imitating (bencmark) of what a competitor's business strategy is already in the first business. With a few modifications tailored to the resources owned both capital and

skill. So, it is common that a company closed because it is not able to compete in seizing the consumer, but there are many who can grow well side by side with their competitors. According to the authors' observations, those who can survive are the companies which carefully look at opportunities by adjusting their resources and are always creative in asking community members. An example is an informant named Siti Asnah. She is from a roadside business who finally has a distinctive product that continues to grow its sales, even one of the products is Kasturi syrup (name of a typical mango fruits that has typical taste) become welcome drinks in some 3 and 4-star hotels.

\section{Relationship Form}

The form of a growing network of business relationships develop into interpersonal relationships in the form of intimate friends and kinship.

\section{Benefits for Community Members}

Benefits felt by members of the business community, they can have many friends, add insight, easy to get business information, know the source of raw materials / merchandise, know more production techniques, reference techniques competitors in selling, and increase sales.

The table below shows the themes and the supporting quotes themes. Furthermore, the themes generated by each informant is shown in the following table.

TABLE I I

THE THEMES AND SUPPORTING QUOTES

\begin{tabular}{|l|l|}
\hline \multicolumn{1}{|c|}{ Theme } & \multicolumn{1}{|c|}{ Supporting Quotes Themes } \\
\hline $\begin{array}{l}\text { Community, } \\
\text { meaning for }\end{array}$ & $\begin{array}{l}\text { Hipmikindo community consists of } \\
\text { various sectors namely trade, processing } \\
\text { industry, agriculture, plantation, fishery, } \\
\text { and others. } \\
\text { - Need each other } \\
\text { - Win-win solution } \\
\text { - Kinship }\end{array}$ \\
$\begin{array}{l}\text { middle entrepreneurs to micro and } \\
\text { small enterprises. The spread is much } \\
\text { related to marketing techniques, } \\
\text { production, access to information and } \\
\text { others. Activities are meetings } \\
\text { There are 13 districts / cities in South } \\
\text { Borneo. In Balangan there is Sengon and } \\
\text { ginger. But the role of the government is } \\
\text { still limited, therefore community } \\
\text { members cannot expect too much, instead } \\
\text { they should help the government build } \\
\text { micro and small enterprises. Utilization } \\
\text { of community by members for the } \\
\text { development of typical Batik industry of } \\
\text { South B orneo named Sasirangan which } \\
\text { certainly no doubt is Halal. } \\
\text { Furthermore, Hipmikindo facilitates } \\
\text { community members to be patronized by } \\
\text { the government and by CSR Adaro, } \\
\text { Pama, Angkasa Pura, Mandiri Bank, } \\
\text { and others. }\end{array}$ \\
\hline
\end{tabular}


TABLE II, CONT.

\begin{tabular}{|c|c|}
\hline $\begin{array}{l}\text { Community } \\
\text { benefits }\end{array}$ & $\begin{array}{l}\text { Some micro businesses have transformed } \\
\text { into small businesses, and small } \\
\text { businesses have become medium- } \\
\text { sized enterprises }\end{array}$ \\
\hline $\begin{array}{l}\text { Intrapersonal } \\
\text { Roles / } \\
\text { relationships }\end{array}$ & $\begin{array}{l}\text { Cultivate product ideas through } \\
\text { creative ways, unique products, original } \\
\text { raw materials, and more modern } \\
\text { production techniques }\end{array}$ \\
\hline $\begin{array}{l}\text { Quality } \\
\text { relations }\end{array}$ & $\begin{array}{l}\text { Begin by trust, then members ask for } \\
\text { advice to other members in order to move } \\
\text { forward together. } \\
\text { Intrapersonal relationship occurs } \\
\text { through Arisan, cooperative (savings and } \\
\text { loan). Through this form of relationship, } \\
\text { some members have been helped, such as } \\
\text { mushroom farmers and chips people. } \\
\text { Through this form of relationship also } \\
\text { marketing techniques, samples of } \\
\text { packaging, training, technique of } \\
\text { production, disseminated, so that } \\
\text { togetherness more intertwined among } \\
\text { members. } \\
\text { In addition to these interpersonal } \\
\text { relationships, regular meetings with co- } \\
\text { operative departments, agricultural } \\
\text { services and industry \& trade are also } \\
\text { being undertaken to advise small and } \\
\text { micro enterprises. } \\
\text { Business assistance to obtain permits } \\
\text { such as PIRT, micro business license, and } \\
\text { capital access information from banks. } \\
\text { This business community, not without } \\
\text { its weaknesses. One obstacle is the } \\
\text { opportunity to meet directly among } \\
\text { fellow community members is very } \\
\text { limited. In addition, these micro and } \\
\text { small enterprises also have constraints, } \\
\text { such as the recovery of good names } \\
\text { from micro and small enterprises in } \\
\text { Bank Indonesia, } \\
\text { To survive, the raw materials must be } \\
\text { adequately available, customer-oriented } \\
\text { marketing strategies. With regard to } \\
\text { packaging, micro and small enterprises } \\
\text { do not have packaging houses, so this } \\
\text { form of business has not been able to } \\
\text { enter the modern market, consequently, } \\
\text { this form of business cannot meet the } \\
\text { target demand. The solution, some } \\
\text { micro and small businesses to partner } \\
\text { with modern retail with consignment } \\
\text { method. }\end{array}$ \\
\hline Creative Attitude & $\begin{array}{l}\text { Creative means attitude that bring new } \\
\text { ideas to modify product quality } \\
\text { (cleanliness, appearance, taste), always } \\
\text { creative in finding market / buyer, } \\
\text { always try to improve packaging, actively } \\
\text { following the development of training } \\
\text { information, donations from the } \\
\text { government, and so fort. Also, always } \\
\text { update the business information. }\end{array}$ \\
\hline Trust & $\begin{array}{l}\text { Through the community, trust between } \\
\text { one member with other members is }\end{array}$ \\
\hline
\end{tabular}

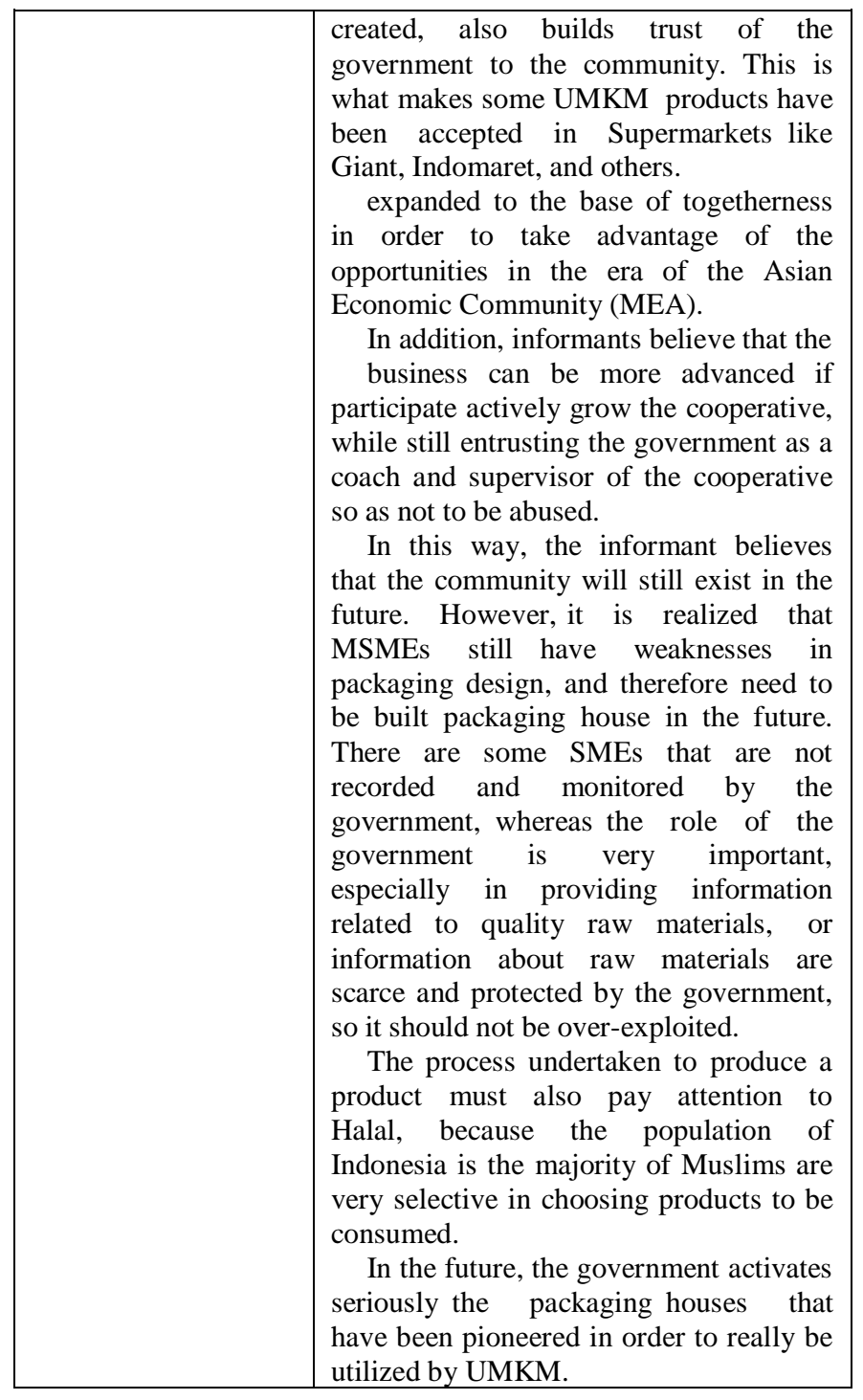

TABLE III

THE RESULTING THEMES

\begin{tabular}{|c|l|l|}
\hline No. & Informants & \multicolumn{1}{|c|}{ Themes } \\
\hline 1 & Asmah Darkani & $\begin{array}{l}\text { Togetherness, sharing of business } \\
\text { information, business assistance, legal } \\
\text { stewardship, trust, and creativity. }\end{array}$ \\
\hline 2 & Hj. Bahrudin & $\begin{array}{l}\text { Mentoring, togetherness, loyalty, sharing } \\
\text { of business information, training, legality } \\
\text { management, mentoring to the bank, and } \\
\text { creative. }\end{array}$ \\
\hline 3 & Siti Asnah & $\begin{array}{l}\text { Training of production, marketing, } \\
\text { packaging, sharing of business } \\
\text { information, cooperation, togetherness, } \\
\text { and creative. }\end{array}$ \\
\hline 5 & M. Nurullah & $\begin{array}{l}\text { Togetherness, mentoring, consulting, } \\
\text { information sharing, networking, } \\
\text { refreshing, and trust. }\end{array}$ \\
\hline
\end{tabular}




\section{DISCUSSIONS}

The purpose of this study is 1 . Understanding the meaning of information exchange among members of the community. 2. Exploring the use of community for the progress of member business. 3 . An important community role for members. Furthermore, this study focuses on the development of an important role of the community in supporting the development of micro and small enterprises in Banjarmasin (South Kalimantan), Indonesia. Here is an explanation of the themes generated in the research:

\section{A. Benefits of community for members}

A strong desire to move forward and grow in business, as well as awareness of limited business knowledge, encourages micro and small businesses to form groups and communicate more intensively. In the beginning, members often meet in the activities organized by government agencies such as the Office of Cooperatives, Industry and Trade (Perindag), Bank Indonesia (BI), and Corporate Social Responsibility (CSR). They interact and share various business information related to the business they run. Technological advancements facilitate the group's desire to communicate more often. Initially only formed a group of BBM, but now community members have turned to social media like WhatsApp (WA).

From the resulting theme mentioned that the benefits of groups that are formed very much perceived by its members, so that the group is important to be maintained and developed. Relationships or interactions that occur, not only limited to exchange of information and transactions between members, but also interpersonal relationships that lead to familial relationships.

\section{B. Forms of Relationship among Members}

The things that underlie the relationship between WhatsApp groups are: same interests, creative, trust and loyalty.

The same interest means the same wants to develop business through networking. Furthermore, members must be creative in modifying and adjusting the rhythm of their business activities with information obtained from the group. Information from the group can be access to raw materials, markets, distribution, packaging, exhibitions, expo, training, seminars, assistance, and others. The growing belief is much dependent on how members genuinely share the true, accurate and reliable information, as well as the recipient of the information believing in the fellow group members so that interpersonal relationships also develop. Members who cannot be trusted slowly will be left out naturally. Finally, loyalty is a logical consequence of satisfaction. In this case, the informant explains that members who have broader knowledge, do not hesitate to help other members without material rewards. Members voluntarily assist other members in arranging the marketing license, Taxpayer Identification Number (NPWP), business license, training, and so forth.

\section{CONCLUSION}

Based on the research results and explanations, the conclusions are shown in the following:

- Sharing of business information among group members of WhatsApp, especially for micro and small entrepreneurs in Banjarmasin has significant roles in growing of members' business.

- Benefits to be gained by group members include business information (access to raw materials, markets, distribution, packaging, and so forth, assistance in handling the business legality, social relations and training information.

- WhatsApp community that is formed can bridge significantly in the business interests of group members.

\section{REFERENCES}

[1] Wahdiyatmoko. (2015). The importance of the sustainable relationship between event organizer and event owner. (Pentingnya hubungan berkelanjutan perusahaan event Organizer dengan Perusahaan pemilik even). Unpublished dissertation. Program Doktor Ilmu Manajemen, Pascasarjana Fakultas Ekonomi Universitas Brawijaya, Malang

[2] Drucker Peter F. (2011). Theory of Business. Forbes. 12/16/2011 http://www.forbes.com/sites/aileron/2011/12/16/theory-of-business.

[3] Firman. 2017. Seven networking benefits for small and medium enterprises (Tujuh Manfaat Networking Untuk Usaha Kecil dan Menegah (UKM) http://idntrepreneur.com/7-manfaat-networkingusaha- kecil-dan-menegah-ukm. diakses 10 Maret 2017

[4] Weisberg Robert W. (1993). Creativity-Beyond the Myth of Genius.2 edition. W.H. Freeman \& co. New York.

[5] Moorman, Christine, Rohit Deshpande, and Gerald Zaltman. (1992). Relationship Between Providers and Users of Market Research: The dynamics of trust whitin and between organizations. Journal of Marketing Research. Vol.29 (August): pp.314-328. 
[6] McKnight D.H., and Chervany N.L. (2002). Conceptualizing trust: a typology and e-commerce customer relationships model. In: Proceedings of the $34^{\text {th }}$ annual Hawai International Conference on System Science (HICSS-34), Maui.

[7] Kotler Philip. (1997). Marketing management: analysis, planning, implementation and control ( $9^{\text {th }}$ ed.). Upper Saddle River, NJ: Prentice Hall.

[8] Oberg, H. and Bell, A. (2012). Exploring phenomenology for researching lived experience in technology enhance learning. In Hodgson V., Jones C., de Laat M., McConnell D., Riberg, T. \& Sloep P.(Eds) The Eighth International Conference on Networked Learning 2012, 2-4 April, Maastriccht School of Management. Maastricht, The Netherlands, pp.203-210.
[9] Aspers Patrick. (2004). Empirical phenomenology an approach for qualitative research. Papers in Social Research Methods, Qualitative Series no.9, Methodology Institute. London School of Economics and Political Science.

[10] Somantri Gumilar Rusliwa.(2005). Understanding qualitative method (Memahami Metode Kualitatif). Makara, Sosial Humaniora. Vol.9.No.2,pp 57-65.

[11] Cresswell, John W. (2007). Qualitative inquiry and research design: choosing among five approaches, $2^{\text {nd }}$ Edition, Sage Publications Ltd. California.

[12] Kleiman, S. (2004). Phenomenology: To wonder and search for meanings. Nurse Researcher, Vol.11(4), pp. 7-19.

[13] Narbuko, Cholod, dan Ahmadi, Abu. (2002). Research methodology (Metodologi Penelitian). Bumi Aksara. Jakarta. 